\title{
Drivers of credit union penetration: An international analysis
}

\author{
Michael Adusei $^{1}$ | Ngozi Adeleye ${ }^{2}$ | Anthony Okafor ${ }^{3}$
}

${ }^{1}$ Kwame Nkrumah University of Science and Technology, Kumasi, Ghana

${ }^{2}$ Department of Economics and Development Studies, Covenant University, Ota, Nigeria

${ }^{3}$ University of Louisville, Louisville,

Kentucky, USA

\section{Correspondence}

Michael Adusei, Kwame Nkrumah University of Science and Technology, Kumasi, Ghana. Email: madusei.ksb@knust.edu.gh
We investigate the drivers of credit union penetration with data from 90 countries for the period 2005-2017. Generally, the results show that the number of credit unions, the level of financial development of a country, the level of industrialization of a country, and the institutional environment are significantly supportive of credit union penetration. We conclude that the elimination of restrictions on the formation of credit unions (if any), the adoption of industrialization as development path, the implementation of sound monetary and fiscal policies that promote financial development, and the pursuit of good public governance are crucial for credit union penetration.

\section{1 | INTRODUCTION}

Credit unions ${ }^{1}$ are not-for-profit microfinance institutions (MFIs) owned and controlled by their members established to promote savings and offer credit to "members at a fair and reasonable interest rate" (Henock, 2019). The primary function of credit unions is the delivery of individual financial loans based on collective savings (Da Silva, Leite, Guse, \& Gollo, 2017). The absence of credit unions will result in many people having no access to consumer credit services, mortgage loans, agricultural credit, and mortgages (McKee, Kagan, \& Ghosh, 2019).

The importance of credit unions to the socio-economic development of society is articulated in terms of their promotion of private resources to create savings and as well as their financing of entrepreneurial initiatives culminating in job creation (Guerra Junior \& Silva, 2013). According to World Bank (2007), financial cooperatives fill a significant gap in the market with a sustainable institutional and business model based on a member-owned service organization serving an unserved but bankable clientele with products driven by demand and with sound financial management founded on members' resources and a "savings first" approach to credit discipline. Vilela, Nagano, and Merlo (2007) argue that credit unions allow sections of society to organize the pursuit of solutions to problems of access to credit and banking services, autonomously and independently.

The owner-borrower feature of credit unions in which depositors/owners are usually borrowers suggests that their ability to mobilize more members carries some critical implications for their sustainability. The performance of credit unions in a given country in terms of mobilizing members is called credit union penetration. To effectively utilize credit unions as tools for promoting financial inclusion and alleviating poverty, policymakers must know the factors that drive their penetration. Despite the policy relevance of these factors, the credit union literature (e.g., Amoah, Aboagye, Bokpin, \& OheneAsare, 2018; Henock, 2019; McKillop \& Quinn, 2017; Unda \& Ranasinghe, 2019) is yet to delineate them. This study attempts to fill this void. Do credit unions penetrate more when the development path of a country is industrialization? Do robust institutions support or slow down credit union penetration? These are some of the questions the study seeks empirical answers to. In doing this, we construct panel data from the annual statistical reports compiled by the World Council of Credit Unions (WOCCU) covering 2005 to 2017.

Three reasons justify this study. First, the findings of this study should broaden the horizon of the extant literature on the social performance of credit unions. Second, an insight into the impact of country context on credit union penetration, for example, has the potential to guide investment funds interested in channeling their loanable funds through credit unions for the dual purpose of earning some decent returns and achieving social impact. Third, answering the question of the drivers of credit union penetration has an inherent effect of highlighting the possible connection between credit unions and the idiosyncratic features of the study countries.

The various estimations using static and dynamic estimators have yielded the following outcomes. The number of credit unions; the level of financial development; industrialization; and political stability; the rule of law; and the regulatory quality variables have emerged as factors that improve credit union penetration in the study countries. The implication is that holding other factors constant, an improvement in any of these variables is likely to drive credit union penetration 
positively. On the other hand, the rural population, gender inequality, and human development have come up as slowing down credit union penetration. It follows that holding other factors constant, an increase in any of these variables should undermine the capacity of credit unions to sign on the more economically productive population of the study countries. Because we are not aware of any empirical investigation into the drivers of credit union penetration using country-level data, these results represent the contribution of this study to knowledge.

The rest of the paper follows this order. Section 2 focuses on the background and empirical review. Section 3 explains the methods adopted for the study. Section 4 discusses the results. Section 5 focuses on the conclusion of the paper.

\section{2 | BACKGROUND AND EMPIRICAL REVIEW}

\section{1 | Background}

MFIs are known as channels for promoting financial inclusion among the poor and financially excluded. Their lending methodologies, including group lending, allow them to reach out to those at the lowest end of the economic spectrum who, for reasons such as nonviability, lack of collateral, and absence of credible credit histories, are avoided by the traditional banking system. They promote microentrepreneurship through the development and delivery of tailormade microloans to poor entrepreneurs and households who access such loans mostly on favorable terms to engage in productive economic activities. Apart from microloans, MFIs also provide services such as remittances, microinsurance, and electronic banking (Tchakoute Tchuigoua, 2016). Pioneered by Muhamad Yunus in Bangladesh, MFIs have, over the years, grown exponentially to represent a crucial layer in the financial architecture of most developing economies. Indeed, the conferment of the Nobel Peace Award on Muhamad Yunus in 2006 could mean the recognition by international organizations of the monumental role of microfinance in the development of financial markets in developing economies.

Differences exist among MFIs. They differ in terms of their legal status and commercial orientation. Concerning legal status, the literature identifies microbanks, nongovernmental organizations (NGOs), cooperatives/credit unions, and nonbank financial institutions (Liñares-Zegarra \& Wilson, 2018). In terms of commercial orientation, there are for-profit and not-for-profit MFIs. With financial inclusion and poverty reduction as their social mission, the not-for-profit MFIs focus on delivering credit and other financial services to the poorest in the economic spectrum in such a way as to enable them to cover their operating costs. In contrast, the for-profit MFIs offer financial services to clients who cut across the entire income distribution. Due to their commercial orientation, they are usually reluctant to serve the more deprived communities.

Among the not-for-profit MFIs are credit unions. They are financial cooperatives organized to satisfy the needs of their members.
They distribute surplus or profits to their clients in the form of dividends, reinvestment in the unions, and lower interest rates on loans. They are governed by unpaid volunteer officers and directors who are elected from the membership of the unions and charged with the responsibility of determining the policies under which the unions should operate. They operate on the cooperative principle: one-man-one-vote irrespective of savings or loan balance (Mckillop \& Wilson, 2011). They are tax exempt in many countries due to the role they play (Mckillop \& Wilson, 2015). Theoretically, credit unions are defined by a common bond. $^{2}$ The common bond might restrict membership to a local community, employees of a particular firm, or individuals with some other organizational affiliation. The original purpose of the common bond is to enable members to substitute collateral with their knowledge of each other's creditworthiness. Credit unions perform a crucial role, even in advanced countries.

Mckillop and Wilson (2015) identify four ways in which credit unions differ from banks. First, they serve their members characterized by a common bond (i.e., the social glue that binds members together). Second, they serve members who are deemed too risky by mainstream financial institutions. Third, they are tax exempt in many countries because of their role in providing financial services to those of modest means. Fourth, they are not required to simultaneously satisfy shareholders' profit expectations and disparate customer needs (Mckillop \& Wilson, 2015).

\section{2 | Empirical review}

Previous research on credit unions/financial cooperatives has looked at diverse issues except for the factors that drive credit union penetration. Goddard, Mackillop, and Wilson (2008) examine the impact of revenue diversification on the financial performance of US credit unions for the period 1993-2004. They observe that on both riskadjusted and unadjusted returns measures, a positive direct exposure effect is outweighed by a negative indirect exposure effect for all but the largest credit unions. Mathuva (2016) assess the impact of revenue diversification on the financial performance of 212 deposit-taking savings and credit cooperatives (SACCOs) in Kenya over the period 2008-2013. The study demonstrates that increased dependence on noninterest income is associated with higher returns. It shows that SACCOs with more diversified revenues record volatile returns. SACCOs with less concentrated revenue streams are characterized by higher volatility in returns. Da Silva et al. (2017) analyze the financial and economic performance of credit unions of major Brazilian credit cooperatives and observe that Uniprime Northern Paraná, Sicoob Cocred, and Sicredi North RS/SC as outstanding cooperatives in terms of efficiency.

McKillop and Quinn (2017) examine the business model complexity of Irish credit unions using a latent class approach to measure structural performance over the period 2002 to 2013 . The study finds a three-class system to be appropriate with the multiclass model dependent on three financial viability characteristics. The study also observes relative performance differences for each class in terms of 
technical efficiency and that two of the classes are subject to diseconomies of scale.

Hessou (2017) deploys data from 100 largest credit unions in Canada covering 1996 to 2014 to analyze the importance of the Basel III additional capital buffer requirements for credit union prudential regulation. The study observes that Canadian credit union capital buffers behave counter-cyclically over the business cycle. Further, credit unions keep a capital buffer bigger than the maximum buffer required under Basel III, which is $5 \%$ of risk-weighted assets.

Liñares-Zegarra and Wilson (2018) investigate the relationship between size and growth. The study relies on a sample of MFIs with different ownership forms (microbanks, NGOs, cooperatives/credit unions, and nonbank financial institutions) and commercial orientation (profit and not-for-profit) collected from 120 countries over the period 2000 to 2014 . The study finds little evidence that size offers growth advantages to MFIs.

Amoah et al. (2018) interrogate the discretional and nondiscretional factors that impact loans credit unions lend to their members and find that size, profitability, management quality, and solvency positively associated with credit union loan business. The study shows that loan loss, net worth, nonloan income, and nonloan activities are negatively associated with credit union loan business. The study further demonstrates that contractionary monetary policy increases the demand for credit union loan.

Unda and Ranasinghe (2019) assess the impact of board of directors' pay on insolvency risk in Australian credit unions and find, among other things, that both voluntary boards and highly paid boards are more likely to reduce insolvency risk. However, depending on the size of the credit union, the effect of board remuneration has two distinct effects on insolvency risk. Whereas volunteer boards are linked with less probability of insolvency risk in smaller credit unions, highly paid boards are associated with less probability of insolvency risk in larger credit unions.

We seek to add to the above literature by identifying the factors that account for credit union penetration. Many country context factors could influence credit union penetration. One of them is economic growth that may create a higher demand for goods and services as well as open up opportunities for expansion of microenterprises (Hermes \& Hudon, 2018). It may correlate with growth in demand for microcredit. A growing economy may increase the current and expected incomes of households, which may fuel their desire for entrepreneurship. Thus, economic growth may lead to more credit union penetration.

On the other hand, credit unions are also likely to flourish in a weak economy. Slack in the growth of an economy may result in demand substitution where imports or higher quality goods are substituted with goods produced by microenterprises (Ahlin, Lin, \& Maio, 2011). Furthermore, credit unions are likely to attract more members during economic recession or crisis because the demand for the services of credit unions may increase as poor households lose their jobs in the formal economy and have to turn to the activities in the informal sector for survival. Most clients of MFIs access microcredit for microentrepreneurship (Mahmood, 2011). Therefore, an improvement in an economy that usually comes with some rise in wage-earning opportunities may drive away existing and potential clients of credit unions as well as worsen nonperforming loans in such institutions. It may be due to the tendency of existing clients to renounce their interest in their relationships with the institutions. Credit unions may not be able to penetrate a growing economy because the demand for microfinance services may decrease as households and entrepreneurs can fund projects from profits or can source funds from traditional sources of finance such as banks. A deteriorating economy may create less demand for savings and loan services from credit unions because business opportunities become scarce in such an economy. It is also possible for macroeconomic conditions to have a neutral effect on credit union penetration. It may occur where most of the clients of credit unions are in the informal sector, and the sector is unrelated to the formal sector.

Does the level of a country's financial development accelerate or slow down credit union penetration? The development of the domestic financial system may slow down credit union penetration as current and potential clients of credit unions may switch to formal financial institutions such as commercial banks for reasons of lower costs, more options, and more flexibility. Again, in a more developed financial system, commercial banks may take to offering financial services to the poor if they observe that MFIs are making some decent returns from lending to the poor. It may cause credit unions to lose clients leading to a fall in their penetration rates. On the other hand, credit unions are likely to mobilize more customers and achieve a better financial performance in countries where financial markets are weak (Cull, Demirguc-Kunt, \& Morduch, 2013; Vanroose \& D'Espallier, 2013), as the poor and financially excluded may consider MFIs as their only hope.

The institutional environment of credit unions may significantly predict their ability to attract more members. The institutional environment provides possibilities and constraints on entrepreneurship, which may affect the membership of credit unions. Credit unions are likely to flourish in the atmosphere of clear property rights, the strict rule of law, and an effective government that formulates businessfriendly policies (Hermes \& Hudon, 2018). On the other hand, a robust institutional environment may impede microentrepreneurship leading to less demand for the services of credit unions, hence, low penetration rate. For instance, an influential government may imply more rules and regulations. These rules and regulations create higher costs for small-scale entrepreneurs and, thus, decrease the demand for financial services offered by credit unions. A growing corruption saps the resources of microenterprises and blocks their expansion, slowing down the demand for MFI services, which may undermine credit union penetration. On the other hand, a growing corruption may facilitate the circumvention of existing regulations, pushing existing and potential customers out of the formal sector into the informal sector, which may lead to a higher demand for the services of credit unions.

Is the political system of a country a significant predictor of credit union penetration? With strong political accountability, politicians are more likely to pursue policies and programs that support entrepreneurship. It may increase demand for credit unions as indigent 
entrepreneurs may seek financial assistance from credit unions for their entrepreneurial exploits. The lack of transparency in the political system of a country may compel economic actors to show interest in the informal sector, driving up demand for credit unions, other things being equal. Political instability is unfriendly to entrepreneurship and, thus, may decrease demand for credit unions. On the other hand, political stability may promote economic activities in the informal sector, which may accelerate demand for credit unions.

Does the number of credit unions in a given country positively correlate with the credit union penetration rate? The answer is not straightforward because where country-context conditions do not favor microfinance activities, a mere multiplication of credit unions will not promote penetration. It presupposes that the effect of the number of credit unions in a given country may be contingent on the prevailing economic circumstances.

\section{3 | DATA SOURCES AND VARIABLES}

\subsection{Data}

Data on credit union penetration and the number of credit unions in each country are obtained from WOCCU at www.woccu.org. WOCCU is the world apex body of credit unions. Among other things, WOCCU advocates internationally to achieve better legislative and regulatory outcomes for credit unions and other cooperative financial institutions and their members. Also, it provides education and global networking for the exchange of information and ideas (WOCCU, 2017). There are 89,026 credit unions in 117 countries from six continents, with 260,164,742 members (WOCCU, 2017).

Credit union penetration rate is modeled by the macroeconomic, institutional, and aggregate number of credit unions in a given country. The study gathers data on per capita gross domestic product (GDP) growth rate, labor force participation rate, rural population as a share of the total population of a country, and credit to the private sector as a share of GDP from the World Development Indicators. The study also gathers the human development index, gender inequality index, and female to male unemployment ratio data from UNDP (2018) at hdr.undp.org. Governance variables (political stability and absence of violence/terrorism; regulatory quality; the rule of law, voice, and accountability; control of corruption; and government effectiveness) are obtained from Worldwide Governance Indicators (WGI) (2018) at datalog.worldbank.org.

The study covers 2005 to 2017 fiscal years. Data availability has dictated this period. The annual statistical reports compiled by WOCCU, which aggregate the statistics of credit unions in countries, cover 2005 to 2017 . The sample for the study is built based on two specific criteria. To be included in the sample, a country must first have at least 5-year data on penetration rate out of the 13-year data expected from each country (2005-2017). Second, the country must have at least 4-year data on the explanatory variables in the model adopted for the study. The application of these criteria yields a sample of 90 countries with the following distribution: 22 African countries,
2 North American countries, 6 South Pacific countries, 14 Latin American countries, 11 European countries, 15 Caribbean countries, and 20 Asian countries. The distribution of the sample reflects its geographical diversity.

\section{2 | Variables}

\subsection{1 | Dependent variable}

The study adopts WOCCU's definition of credit union penetration rate: the total number of credit union members divided by the economically active population age 15-64 years old. The higher this ratio, the greater the penetration rate of credit unions in a country.

\subsection{2 | Explanatory variables}

Many explanatory variables are employed to model credit union penetration. The number of credit unions in a country should influence credit union penetration positively. Thus, the natural logarithm of the number of credit unions is included in the model. Per capita GDP growth rate is used to gauge the state of economic progress of each country. As explained above, a priori its effect on credit union penetration is unclear.

The inclusion of workforce participation rate in the model is important because it measures the prevalence of labor opportunities in a given country, which may support or rival the ability of credit unions to attract members. It is measured by dividing the labor force in a country by the population aged 15 or above.

Poverty is usually higher in rural areas, especially in developing countries. It explains why many microfinance activities are rural-centered, where it is estimated that about $75 \%$ of indigent people in developing countries dwell, surviving directly or indirectly on agriculture (Dorfleitner, Just-Marx, \& Priberny, 2017). Therefore, credit unions are likely to flourish in a country that has a higher proportion of its population living in rural areas. Percent of the population in rural areas is, thus, one of the variables in this study. Its effect on penetration is expected to be positive.

We measure the degree of financial development of a country by the credit to the private sector as a share of GDP. Its effect on penetration could be negative or positive. However, in this study, we expect the effect to be positive.

We take into account the extent of human development of a country in which credit unions operate by capturing the human development index obtained from the United Nations Development Program (UNDP) in the model. The index measures the standard of living, life expectancy, and education. A higher value suggests higher productivity of labor, which may have positive or negative consequences for the ability of credit unions to mobilize more members. That notwithstanding, we predict that it should have a negative impact on credit union penetration. Another variable that is also obtained from the UNDP is the gender inequality index. It is a composite index using 
three dimensions: reproductive health, empowerment, and the labor market. A high index indicates high inequality between women and men and vice versa. To the extent that MFIs target women who are most disadvantaged (Strøm, D'Espallier, \& Mersland, 2014), a rising inequality between women and men should support credit union penetration and vice versa. The same argument is advanced for the effect of unemployment on credit union penetration. As the unemployment ratio between females and males rises in a given country, this is likely to support credit union penetration, holding other factors constant.

All things being equal, when industrialization is the development path of a country, income-earning jobs are created that improve standard of living. As people's standard of living improves, they are more likely to prefer transacting business with the mainstream financial institutions than credit unions, holding other factors. We, therefore, expect industrialization to slow down credit union penetration.

Finally, we capture the institutional environment in the model by adding the six WGI: political stability and lack of violence; control of corruption; the rule of law; regulatory quality; government effectiveness; and voice and accountability. A higher value of any of these six variables suggests a better institutional outcome and vice versa. Due to the high correlation among them, they will enter the model one after the other. It requires estimating the estimation of six versions of the model developed for this study. Table 1 summarizes the variables and their expected effects on credit union penetration.

Table 2 presents the descriptive statistics of the variables. The table reveals that the mean, minimum, and maximum values of credit penetration rate is $19.49,0.03$, and 4193 , respectively. These statistics inform us that on average, credit unions in the sample have recorded about $19.49 \%$ penetration rates with $128.122 \%$ deviation from the mean value. Outliers are observed in the sample. One of such is the financial development variable. Hence, to correct outliers and establish an elasticity relationship, we use the natural logarithms of variables with nonnegative values.

The correlations among the variables are checked by the Pearson correlation matrix in Table 3. The correlations between pairs of explanatory variables are well within acceptable range except those between pairs of WGI. The high correlations between pairs of WGI require that the six indicators should not enter the model at a time; otherwise, the results will be unreliable due to multicollinearity problem.

\section{3 | The model and analytical techniques}

Based on the outcome of the Hausman (1978) test specification, the fixed effects model is chosen over pooled ordinary least squares and random effects models to identify the predictors of credit union penetration. The model is as folllows:

$$
Y_{i t}=\alpha+\beta_{1} X_{i, t}+d t+u_{i t} \ldots \ldots \cdots \cdots \cdots
$$

where $Y_{i t}=$ credit union penetration that is the predicted variable; $X=$ a set of explanatory variables; $\alpha=$ constant; $d_{t}=$ time dummies; $\mu=$ error term; $i$ and $t=$ country and time effects, respectively.

Equation 1 is augmented with the inclusion of lagged dependent variable as a regressor, and a dynamic version of the above model is

TAB LE 1 Variables description, priors, and sources

\begin{tabular}{|c|c|c|c|c|}
\hline Variable & Notation & Definition & Expected sign & Source \\
\hline Credit union penetration & PEN & $\begin{array}{l}\text { Total number of credit union members divided by the } \\
\text { economically active population age } 15-64 \text { years old }\end{array}$ & $N / A$ & WOCCU \\
\hline Credit unions & C.U. & $\begin{array}{l}\text { The natural logarithm of the number of credit unions in a } \\
\text { country }\end{array}$ & - & - do- \\
\hline Economic growth & Growth & Per capita GDP growth rate & - & WDI \\
\hline Workforce participation & WFP & Labor force in a country by the population aged 15 or above & + & - do- \\
\hline Rural population & RURAL & Percent of the population in rural areas & - & -do- \\
\hline Financial development & FINDEV & Credit to the private sector as a share of GDP & + & -do- \\
\hline Human development & H.D. & Human development index & - & UNDP \\
\hline Gender inequality & GII & Gender inequality index & + & -do- \\
\hline Unemployment & UNEMP & Female to male unemployment ratio & + & - do- \\
\hline Industrialization & INDUS & Manufacturing (value added) as a share of GDP & - & -do- \\
\hline Political stability and lack of violence & PSTAB & Political stability and lack of violence index ( -2.5 to 2.5$)$ & + & WGI \\
\hline Control of corruption index & CORRUP & Control of corruption index ( -2.5 to 2.5$)$ & + & -do- \\
\hline Rule of law index & ROL & Rule of law index ( -2.5 to 2.5$)$ & + & -do- \\
\hline Regulatory quality & RQUAL & Regulatory quality index ( -2.5 to 2.5$)$ & + & -do- \\
\hline Government effectiveness & GEFF & Government effectiveness index ( -2.5 to 2.5$)$ & + & -do- \\
\hline Voice and accountability & VACC & Voice and accountability index ( -2.5 to 2.5$)$ & + & -do- \\
\hline
\end{tabular}

Abbreviations: WGI, World Governance Indicators; WDI, World Development Indicators; WOCCU, World Council of Credit Unions. Source: Authors' compilations. 
TABLE 2 Descriptive statistics

\begin{tabular}{|c|c|c|c|c|c|}
\hline Variable & Obs & $M$ & $S D$ & Min & Max \\
\hline PEN & 1099 & 19.485 & 128.122 & 0.03 & 4193 \\
\hline CUs & 1112 & 632.367 & 1676.378 & 1 & 20,193 \\
\hline RURAL & 1105 & 49.91 & 21.751 & 4.76 & 87.022 \\
\hline GROWTH & 1153 & 2.689 & 3.924 & -18.491 & 32.997 \\
\hline GII & 700 & 0.422 & 0.16 & 0.063 & 0.742 \\
\hline UNEMP & 738 & 1.3 & 0.498 & 0.47 & 3.25 \\
\hline INDUS & 1109 & 11.85 & 6.315 & 0.755 & 34.566 \\
\hline HDI & 1118 & 0.668 & 0.151 & 0.283 & 0.939 \\
\hline PSTAB & 1170 & -0.126 & 0.848 & -2.781 & 1.593 \\
\hline GEFF & 1170 & -0.105 & 0.896 & -2.085 & 2.437 \\
\hline VACC & 1166 & -0.008 & 0.85 & -2.313 & 1.629 \\
\hline
\end{tabular}

Abbreviations: CORRUP, control of corruption; CUs, Number of credit unions; FINDEV, financial development; GEFF, government effectiveness; GII, the gender inequality between females and males; GROWTH, economic growth; HDI, human development index; INDUS, industrialization; PEN, penetration rate of credit unions; PSTAB, political stability; ROL, rule of law; RURAL, rural population; UNEMP, the unemployment ratio between females and males; VACC, voice and accountability; WFP, workforce participation.

estimated by the two-step difference generalized method of moments (GMM) estimation technique (Arellano \& Bond, 1991; Arellano \& Bover, 1995; Blundell \& Bond, 1998). The GMM approach is an advanced 2SLS-IV procedure (Roodman, 2009, 2014). The conventional IV estimator is also inefficient in the presence of heteroskedasticity. Arellano and Bond (1991) developed the difference GMM. Arellano and Bover (1995) and Blundell and Bond (1998) developed the system GMM. GMM is known to correct simultaneity and endogeneity problems associated with panel regressions. The appeal of GMM techniques is attributed to the following: they control for unobserved firm-specific effects; they first-difference nonstationary variables; they overcome the endogeneity of the explanatory variables by using instruments; and they test for the presence of autocorrelation (Saci, Giorgioni, \& Holden, 2009). The basic differences between the system and difference GMM approaches are that the system GMM estimator involves a set of additional restrictions (more instruments) on the initial conditions of the process generating the dependent variable (Roodman, 2009). Either the system or difference GMM is a valid dynamic panel data technique. However, we find the two-step difference GMM approach a sufficient method that satisfies the objectives of the study. The use of two-step difference GMM is consistent with Adeleye, Adedoyin, and Nathaniel (2020); Abrate, Piacenza, and Vannoni (2009); Waziri, Mohamed Nor, Raja Abdullah, and Adamu (2015); Chen and Kao (2014); Aali-Bujari, Venegas-Martínez, and Pérez-Lechuga (2016); Siddiqui and Ahmed (2013); and Gnangoin, Du, Assamoi, Edjoukou, and Kassi (2019).

\section{4 | REGRESSION RESULTS AND DISCUSSIONS}

\section{1 | Baseline results}

Due to the high correlations among the WGI variables, a nested regression approach is adopted in which the governance indicators enter the model one after the other. Approximately, across the six regression specifications, the explanatory power of the independent variables in explaining the variations in credit union penetration is $34 \%$. Consistently, a $1 \%$ change in the number of credit unions is associated with about $21 \%$ increase in credit union penetration, ceteris paribus. It occurs at a $1 \%$ significance level. Thus, our prediction of a positive relationship between the number of credit unions and credit union penetration is supported. It is understandable because as the number of credit unions springs up in a country, this enhances the chances of attracting more members.

An improvement in the domestic financial system of a country supports the development of credit unions. A $1 \%$ change in financial development causes a $20 \%$ increase in credit union penetration rate, holding other factors constant. It may be due to the opportunity for credit unions to learn best practices from the traditional financial institutions in developed financial systems, which makes them attractive alternatives to traditional financial institutions. This observation runs counter to Cull et al. (2013) and Vanroose and D'Espallier (2013) who posit that credit unions mobilize more customers and achieve a better financial performance in countries where financial markets are weak. 


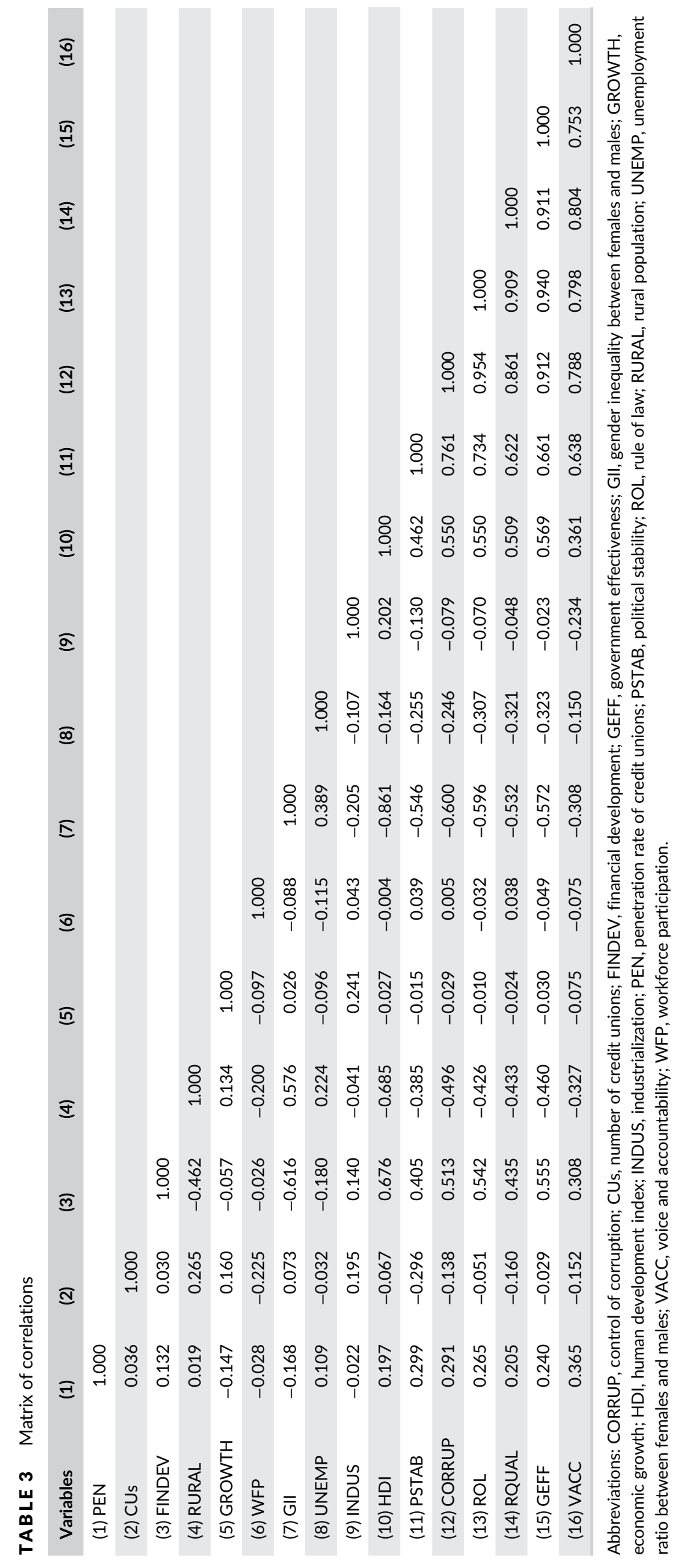


It means our expectation of a positive relationship between financial development and credit union penetration is upheld.

Typically, the income levels of the population in rural areas are low due to low and less productive economic activities in such areas. Furthermore, because MFIs, including credit unions, usually target the poor and financially excluded, it is reasonable to expect some positive relationship between credit union penetration and the percent of the rural population. Surprisingly, the results in Table 4 suggest some rivalry between credit union penetration and rural population. Across the six regressions, a percentage increase in rural population results in about a $4 \%$ drop in credit union penetration rate. This runs counter to the prediction of a positive relationship between rural population and credit union penetration. The modus operandi of credit unions, which requires some basic level of income to qualify for membership, may explain this outcome. Unlike NGOs, membership of a credit union requires some income for registration and deposit. MFIs serve low-income persons as well as small and informal businesses in developing and newly industrialized countries (Tchakoute Tchuigoua, 2016). In most cases, poverty is severe in the rural areas of these countries. The lack of income for registration and deposit may drive potential clients of credit unions to other forms of MFIs such as NGOs.

Industrialization proxied by manufacturing (value-added) as a share of GDP comes up as complementing credit union penetration. The results in Table 4 reveal that between 34\% and 39\% variations in credit union penetration are accounted for by industrialization. A percentage increase in industrialization triggers between 34\% and 39\% change in credit union penetration rate holds other factors constant. It can be attributed to the cooperative principles of credit union that require some savings before becoming a member of a credit union. Industrialization offers opportunities for job creation. Access to job opportunities improves income levels that support credit union penetration. The implication is that our expectation that it should slow credit union penetration is unsupported.

MFIs target women (Strøm et al., 2014) who are most disadvantaged. According to Strøm et al. (2014), women quickly access leadership positions in the often more mission-driven NGOs and cooperatives. Thus, other things being equal, a rising inequality between women and men should support credit union penetration. However, it appears that credit unions are not likely to mobilize more members in a rising inequality between women and men. This is because, in Table 4, gender inequality between women and men exhibits a negative and statistically significant effect on credit union penetration. It occurs at the $10 \%$ significance level. It means that our expectation of a positive relationship is not met.

Table 4 shows that three of the WGI capturing the institutional environment of the countries in this study (political stability and absence of violence; the rule of law; and regulatory quality) come up as complementing credit union penetration. A unit change in political stability and absence of violence score of a country cause about $30 \%$ $(p<.0000)$ increase in credit union penetration. Political stability promotes economic activities in the informal sector leading to an increase in the demand for credit unions. The rule of law supports credit union penetration. It captures "perceptions of the extent to which agents have confidence in and abide by the rules of society, and in particular the quality of contract enforcement, property rights, the police, and the courts, as well as the likelihood of crime and violence." A unit change in the rule of law index of a country is likely to cause about a $48 \%$ increase in the credit union penetration rate of the country, holding other factors constant. Entrepreneurship thrives in an environment where citizens perceive that existing laws, primarily, those relating to property rights, are rigorously enforced. It creates demand for the services of credit unions resulting in high credit union penetration. A similar argument is made for the positive and statistically significant relationship $(p<.0000)$ between regulatory quality and credit union penetration. Holding other factors constant, a percentage increase in the regulatory quality of index of a country results in about $47 \%$ increase in penetration. Regulatory quality measures perceptions of the ability of the government to formulate and implement sound policies and regulations that permit and promote private sector development. Entrepreneurship, especially microentrepreneurship, flourishes in a country whose government can formulate and implement sound policies and regulations that support private sector development. When this occurs, demand for financial services, including the services offered by credit unions, rises, leading to an increase in credit union penetration. The implication of the prediction that these three governance variables should drive credit union penetration positively is supported.

Contrary to our prediction, three governance variables (control of corruption, government effectiveness and voice, and accountability) show no significant impact on credit union penetration. Similarly, across the six columns in Table 4, GDP growth rate, unemployment ratio, and work participation exhibit no significant effects on credit union penetration.

\section{2 | Robustness checks}

The per capita GDP growth rate is substituted with per capita GDP (\$) to check the robustness of the results in Table 4. Besides, foreign direct investment is introduced as an additional explanatory variable. A country's development path may be based on foreign direct investment flowing into the country. More inflows from foreign economies into a domestic economy may improve economic activity that can lead to demand for more financial services in both formal and informal sectors. It may lead to an improvement in credit union penetration. On the other hand, an improvement in an economy occasioned by foreign direct investment may siphon customers away from the informal sector to the formal sector that may affect the ability of credit unions to get more members.

Table 5 presents the results of the new estimations. As can be observed, the effects of the significant variables identified in Table 4 have not changed. GDP per capita does not exhibit any significant relationship with credit union penetration under all the estimations. Under the six estimations, foreign direct investment shows up as supporting credit union penetration. Approximately, a $1 \%$ rise in 
s

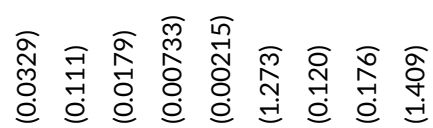

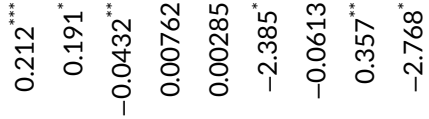

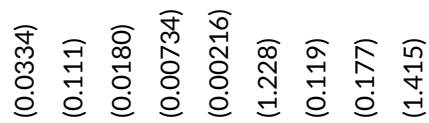

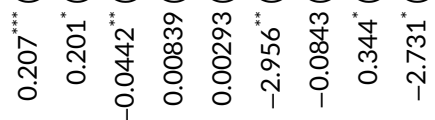

ธู

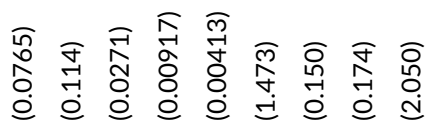

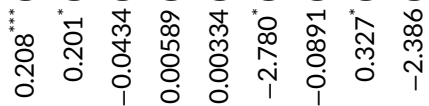

হ)

응 의 0 의

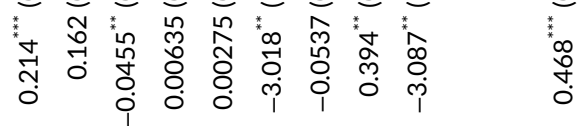

ल

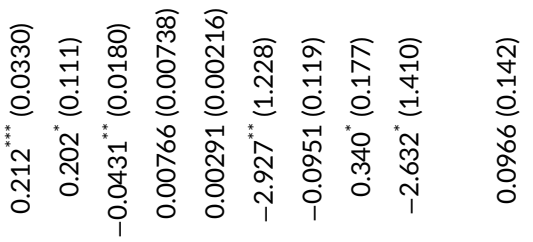

ธู

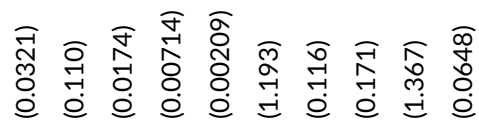

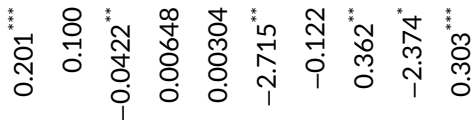

$\Xi$

$$
\begin{gathered}
1 \\
0 \\
0
\end{gathered}
$$

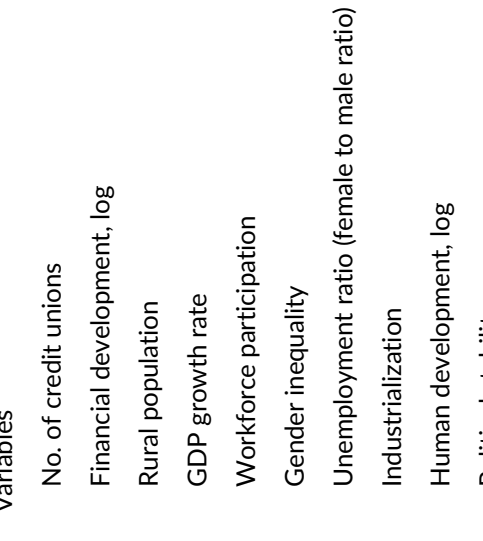

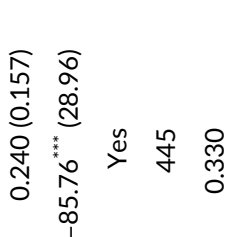

ঙำ

$\stackrel{\substack{n \\ \hdashline}}{\circ}$

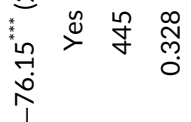

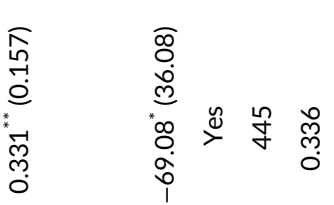

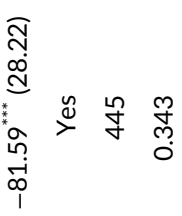

ठิ

वे

敬

要

这

这语

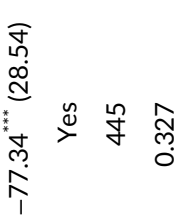

这

ह

嶂

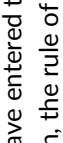

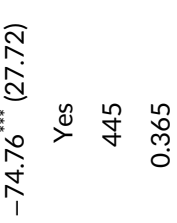

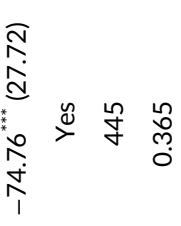

$\sum^{2} \frac{0}{0}$

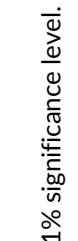

$\stackrel{\circ}{\circ}$

产

*

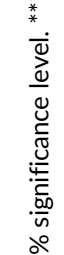

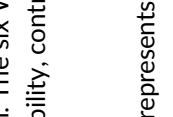

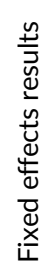




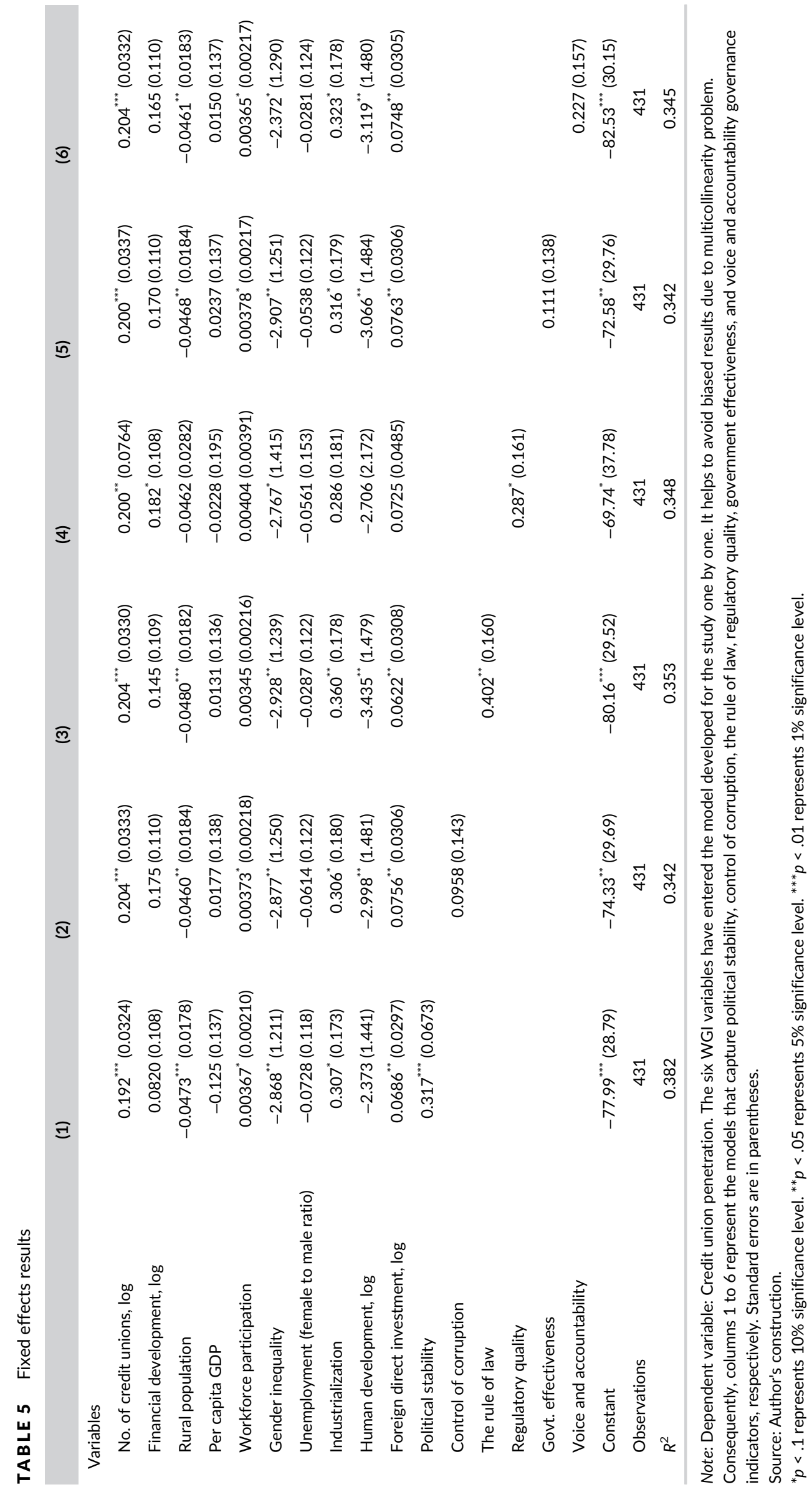




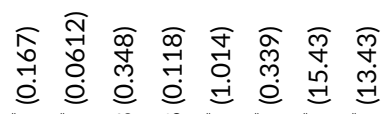

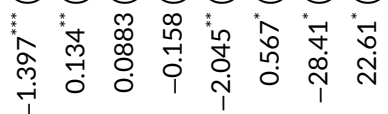

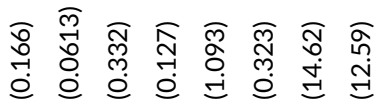

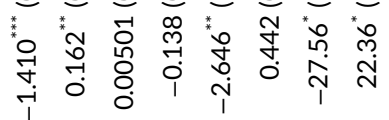

ถู

平

ल

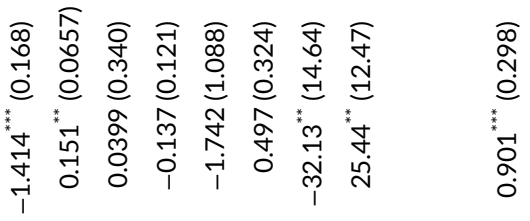

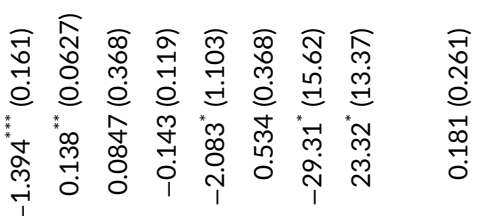

สิ

ชิํำ

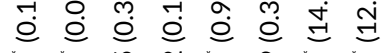

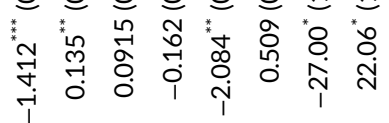

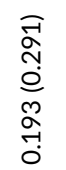

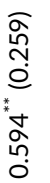

did

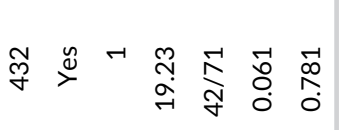

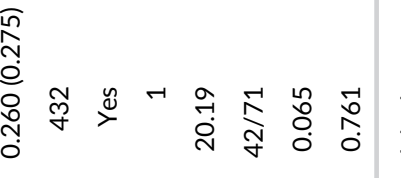

章

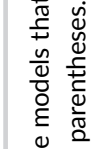

昰

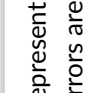

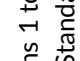

言

䒽

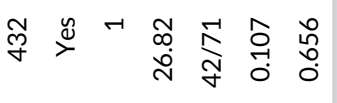

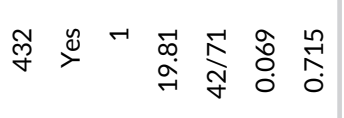

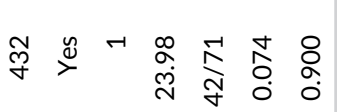

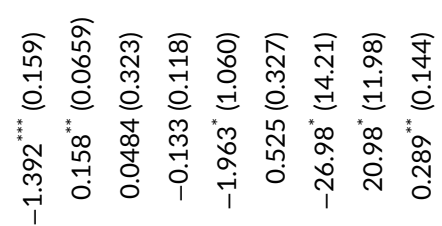

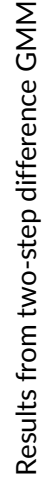

$\Xi$

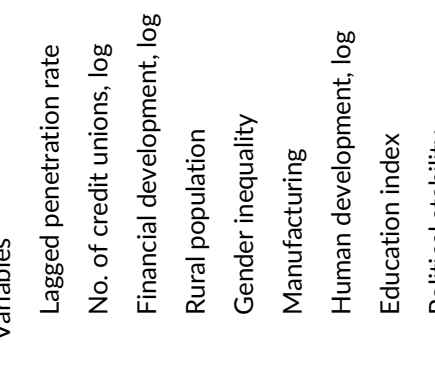

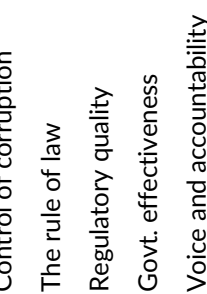

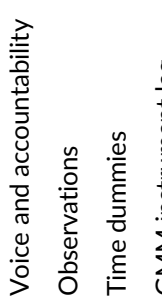

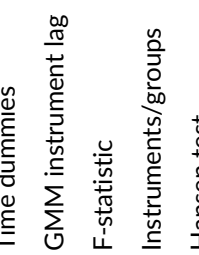

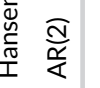

잔

范 
foreign direct investment results in about a 7\% rise in credit union penetration, holding other factors constant.

The robustness of the results is also checked by transforming the baseline model into a dynamic one and estimating it with two-step robust difference GMM. ${ }^{3}$ Two-step difference GMM is efficient and robust to heteroscedasticity and autocorrelation (Roodman, 2009). In estimating the difference GMM, the insignificant variables reported in Table 4 enter as instruments. The model is augmented by education index obtained from UNDP as an additional variable. It is assumed to be an internal variable. Table 6 shows the results of the GMM estimations. The diagnostics reported below the table establish the validity of the results. The Hansen statistic is insignificant at the $5 \%$ level. Hence, we fail to reject the null hypothesis of over-identifying restrictions in the model.

The positive coefficients of the number of credit unions, political stability, the rule of law, and regulatory quality have not changed except that the coefficient of regulatory quality is now statistically insignificant. Government effectiveness has now emerged as a significant predictor of credit union penetration rate. The coefficients of industrialization, gender inequality, human development, rural population, and financial development have also not changed. However, the coefficients of industrialization, rural population financial development are now statistically insignificant, save the results in column 6, which reveal industrialization as supporting credit union penetration.

\subsection{Other robustness checks}

Using the year 2009 as the terminal point of the global financial crisis, we split the dataset into two: 2005-2009 and 2010-2017 and ran new regressions. We did not observe any significant results that differed from the baseline results. They are not reported but are available upon a reasonable request. Besides, we followed the example of Matemilola, Bany-Ariffin, Azman-Saini, and Annuar (2019) to reduce the six governance indicators into one index by finding the average index. We then used it to perform a new set of regressions. No results different from the baseline results were observed. They are not reported but are available if requested.

\section{5 | CONCLUSION}

This paper addresses the question of significant predictors of credit union penetration using data from 90 countries drawn from across the globe. Dictated by data availability, the study covers 2005 to 2017. Guided by the Hausman (1978) test for panel regression specification, the study has deployed fixed effects regression technique to identify the significant predictors of credit union penetration. Generally, the baseline results reveal the number of credit unions, the level of financial development, industrialization, political stability, the rule of law, and regulatory quality as significantly supportive of credit union penetration. It suggests that an improvement in any of these variables could accelerate the membership drive of credit unions in the study countries. These results support the conclusion that the elimination of restrictions on the formation of credit unions (if any), the adoption of industrialization as development path, the implementation of sound monetary and fiscal policies that promote financial development, and the pursuit of good public governance are crucial for credit union penetration. On the other hand, the results show that rural population, gender inequality, and human development slow down credit union penetration. In our view, these impeding factors must be addressed alongside the favorable ones to accelerate credit union penetration in the study countries.

We highlight two policy recommendations of our findings. First, to the extent the number of credit unions in a given supports credit union penetration, the removal of any restrictions on the formation of credit unions is likely to improve penetration. However, care should be taken. Experience has shown that poor management of mushroom credit unions that spring up due to less stringent regulation usually creates problems for financial systems. This is because when such credit unions eventually collapse, agitations by their aggrieved members usually attenuate consumer confidence in the entire financial system. Second, it is known from economic theory that industrialization is key to economic development, especially in developing economies where poverty is pervasive. The literature documents that MFIs are more visible in developing economies as tools for promoting financial inclusion and alleviating abject poverty. Therefore, the finding that industrialization drives credit union penetration allows us to contribute to the call for developing economies to embrace industrialization as a path for economic development. However, industrialization cannot be successful without some ingredients. An improvement in the political climate, implementation of effective and efficient regulatory regimes, and upholding the rule of law are some of the vital support systems required for any effective industrialization drive. Policymakers are, thus, advised to pay careful attention to these factors.

It is important to point out one low point of this study. The findings of this study may not be representative of all credit unions in the world in the sense that it is not every credit union that is affiliated to WOCCU. There may be some credit unions that have not reported their data to WOCCU for which reason they are not captured in this study. Notwithstanding this shortcoming, this paper should open the floodgates for more investigations into the social and financial performance of credit unions. Because MFIs differ in many respects, it will be interesting if future research addresses the issues raised in this paper with data from other MFIs. What are the drivers of NGOs penetration? Where do nonbank financial institutions penetrate? These are some of the questions that could be considered by future research.

\section{DATA AVAILABILITY STATEMENT}

The data that support the findings of this study are available from the corresponding author upon a reasonable request. 


\section{ENDNOTES}

${ }^{1}$ They are also called financial cooperatives.

${ }^{2}$ Gradually, this has become less relevant in some countries.

3 The GMM analysis are carried using Roodman $(2009,2014)$ xtabond 2 user-written syntax in Stata. The syntax allows that all the right-hand variables generally appears twice in the command first as regressors and secondly as instruments. They are explicitly specified in the iv() that indicates that they are instrumenting themselves.

\section{REFERENCES}

Aali-Bujari, A., Venegas-Martínez, F., \& Pérez-Lechuga, G. (2016). Impact of derivatives markets on economic growth in some of the major world economies: A difference-GMM panel data estimation (2002-2014). The IEB International Journal of Finance, 12, 110-127. https://doi.org/10.5605/IEB.12.6

Abrate, G., Piacenza, M., \& Vannoni, D. (2009). The impact of integrated tariff systems on public transport demand: Evidence from Italy. Regional Science and Urban Economics, 39, 120-127. https://doi.org/ 10.1016/j.regsciurbeco.2008.05.014

Adeleye, B. N., Adedoyin, F. F., \& Nathaniel, S. (2020). The criticality of ICT-trade Nexus on economic and inclusive growth. Information Technology for Development, 1-22. https://doi.org/10.1080/02681102. 2020.1840323

Ahlin, C., Lin, J., \& Maio, M. (2011). Where does microfinance flourish? Microfinance Institution Performance in Macroeconomic Context. Journal of Development Economics, 95, 105-120.

Amoah, B., Aboagye, A. Q. Q., Bokpin, G. A., \& Ohene-Asare, K. (2018). Firm specific, financial development and macroeconomic determinants of credit union lending. Journal of International Development, 30, 1203-1222.

Arellano, M., \& Bover, O. (1995). Another look at the instrumental-variable estimation of error-components models. Journal of Econometrics, 68, 29-52. https://doi.org/10.1016/0304-4076(94)01642-D

Arellano, M., \& Bond, S. R. (1991). Some tests of specification for panel data: Monte Carlo evidence and an application to employment equations. Review of Economic Studies, 58, 277-297. https://doi.org/ $10.2307 / 2297968$

Blundell, R., \& Bond, S. R. (1998). Initial conditions and moment restrictions in dynamic panel data models. Journal of Econometrics, 87(1), 115-144. https://doi.org/10.1016/S0304-4076(98)00009-8

Chen, T.-Y., \& Kao, L.-J. (2014). Dividend changes and information about future profitability: An application of difference GMM. Applied Economics Letters, 21(7), 505-508. https://doi.org/10.1080/13504851. 2013.870648

Cull, R., Demirguc-Kunt, A., \& Morduch, J. (2013). Banks and microbanks. Journal of Financial Services Research, 46, 1-53.

Da Silva, T. P., Leite, M., Guse, J. S., \& Gollo, V. (2017). Financial and economic performance of major Brazilian credit cooperatives. Contaduría y Administración, 62, 1442-1459. https://doi.org/10.1016/j.cya.2017. 05.006

Dorfleitner, G., Just-Marx, S., \& Priberny, C. (2017). What drives the repayment of agricultural micro loans? Evidence from Nicaragua. The Quarterly Review of Economics and Finance, 63, 89-100. https://doi.org/10. 1016/j.qref.2016.02.009

Gnangoin, Y. T. B., Du, L., Assamoi, G., Edjoukou, A. J., \& Kassi, D. F. (2019). Public spending, income inequality and economic growth in Asian countries: A panel GMM approach. MDPI Economies, 7, 115. https://doi.org/10.3390/economies7040115

Goddard, J., Mackillop, D., \& Wilson, J. O. S. (2008). The diversification and financial performance of U.S. credit unions. Journal of Banking \& Finance, 32, 1836-1849. https://doi.org/10.1016/j.jbankfin.2007.12.015

Guerra Junior, A., \& Silva, L. B. (2013). As cooperativas de crédito mútuo no Brasil. FACEF Pesquisa-Desenvolvimento e Gestão, 16(1).
Hausman, J. (1978). Specification Tests in Econometrics. Econometrica, 46, 1251-1271.

Henock, M. S. (2019). Financial sustainability and outreach performance of saving and credit cooperatives: The case of eastern Ethiopia. Asia Pacific Management Review, 24, 1-9.

Hermes, H., \& Hudon, M. (2018). Determinants of the performance of microfinance institutions: A systematic review. Journal of Economic Surveys, 32(5), 1483-1513. https://doi.org/10.1111/joes.12290

Hessou, H. (2017). Basel III capital buffer requirements and credit union prudential regulation: Canadian evidence. Journal of Financial Stability, 30, 92-110. https://doi.org/10.1016/j.jfs.2017.05.002

Liñares-Zegarra, J., \& Wilson, J. O. S. (2018). The size and growth of microfinance institutions. The British Accounting Review, 50, 199-213. https://doi.org/10.1016/j.bar.2017.11.006

Mahmood, S. (2011). Microfinance and women entrepreneurs in Pakistan. International Journal of Gender and Entrepreneurship, 3(3), 265-274. https://doi.org/10.1108/17566261111169340

Matemilola, B. T., Bany-Ariffin, A. N., Azman-Saini, W. N. W., \& Annuar, M. N. (2019). Impact of institutional quality on the capital structure of firms in developing countries. Emerging Markets Review, 39, 175-209. https://doi.org/10.1016/j.ememar.2019.04.003

Mathuva, D. (2016). Revenue diversification and financial performance of savings and credit cooperatives in Kenya. Journal of Co-operative Organization and Management, 4, 1-12.

McKee, G., Kagan, A., \& Ghosh, A. (2019). Small asset credit union executive succession concerns. Journal of co-Operative Organization and Management, 7, 26-33. https://doi.org/10.1016/j.jcom.2019. 03.001

McKillop, D. G., \& Quinn, B. (2017). Irish credit unions: Differential regulation based on business model complexity. The British Accounting Review, 49, 230-241. https://doi.org/10.1016/j.bar.2016.07.001

Mckillop, D., \& Wilson, J. O. S. (2011). Credit unions: A theoretical and empirical review. New York: New York University Salomon Center and Wiley Periodicals, Inc.

Mckillop, D. G., \& Wilson, J. O. S. (2015). Credit unions as cooperative institutions: Distinctiveness, performance and prospects. Social and Environmental Accountability Journal, 35(2), 96-112. https://doi.org/ 10.1080/0969160X.2015.1022195

Roodman, D. (2009). How to do xtabond2: An introduction to difference and system GMM in Stata. The Stata Journal, 9(1), 86-136.

Roodman, D. (2014). xtabond2: Stata module to extend xtabond dynamic panel data estimator. Boston College Department of Economics: Statistical Software Components.

Saci, K., Giorgioni, G., \& Holden, K. (2009). Does financial development affect growth? Applied Economics, 41, 1701-1707. https://doi.org/10. 1080/00036840701335538

Siddiqui, D. A., \& Ahmed, Q. M. (2013). The effect of institutions on economic growth: A global analysis based on GMM dynamic panel estimation. Structural Change and Economic Dynamics, 24, 18-33. https://doi. org/10.1016/j.strueco.2012.12.001

Strøm, R. Ø., D'Espallier, B., \& Mersland, R. (2014). Female leadership, performance, and governance in microfinance institutions. Journal of Banking and Finance, 42, 60-75. https://doi.org/10.1016/j.jbankfin. 2014.01.014

Tchakoute Tchuigoua, H. (2016). Buffer capital in microfinance institutions. Journal of Business Research, 69, 3523-3537. https://doi.org/10. 1016/j.jbusres.2016.01.034

Unda, L. A., \& Ranasinghe, D. (2019). To pay or not pay: Board remuneration and insolvency risk in credit unions. Pacific-Basin Finance Journal, 101128. https://doi.org/10.1016/j.pacfin.2019.03.005

United Nations Development Programme (2018). Available at hrd. undp.org

Vanroose, A., \& D'Espallier, B. (2013). Do microfinance institutions accomplish their mission? Evidence from the relationship between traditional financial sector development and microfinance institutions' outreach 
and performance. Applied Economics, 45, 1965-1982. https://doi.org/ 10.1080/00036846.2011.641932

Vilela, D. L., Nagano, M. S., \& Merlo, E. M. (2007). Aplicac,ão da análise envoltória de dados em cooperativas de crédito rural. Revista de Administra,cão Contemporânea, 11(SPE2), 99-120. https://doi.org/10. 1590/S1415-65552007000600006

Waziri, S. I., Mohamed Nor, N., Raja Abdullah, N. M., \& Adamu, P. (2015). Effect of the prevalence of HIV/AIDS and the life expectancy rate on economic growth in SSA countries: Difference GMM approach. Global Journal of Health Science, 8(4), 212-220. https://doi.org/10.5539/gjhs. v8n4p212
World Bank (2007). Providing financial services in rural areas. A Fresh Look at Financial Cooperatives (World Bank VI).

World Council of Credit Unions (2017). Available at www.woccu.org

How to cite this article: Adusei M, Adeleye N, Okafor A.

Drivers of credit union penetration: An international analysis.

Manage Decis Econ. 2020;1-14. https://doi.org/10.1002/

mde.3267 